Indonesian Journal of Physics and Nuclear Applications

Volume 1, Number 2, June 2016, p. 116-122

ISSN 2549-046X, C FSM UKSW Publication

\title{
Radionuclide Release Prediction in Water and Soil at Demonstration Plant of Near Surface Disposal for Radioactive Waste
}

\author{
Pandu Dewanto ${ }^{11}$, Setyo Sarwanto Moersidik ${ }^{2}$, Sucipta ${ }^{3}$ \\ ${ }^{1}$ BadanPengawas Tenaga Nuklir, Jakarta, 10120, Indonesia \\ ${ }^{2}$ Program Studi Magister TeknikSipil, FakultasTeknik, UI, Depok, 16424, Indonesia \\ ${ }^{3}$ Badan Tenaga Nuklir Nasional, Kawasan PUSPIPTEK Serpong, 15310, Indonesia
}

Received: 30 June 2015, Revised: 30 September 2016, Accepted: 10 April 2016

\begin{abstract}
Near Surface Disposal (NSD) for Radioactive Waste that should be developed due to increment of the low level radioactive waste, need to be analyzed and evaluated related to the radiological impact of the environment. A research method applied is done by modeling the distribution of radionuclide releases process. Analysis related with the releases of radionuclide in water and soil is using PRESTO (Prediction of Radiological Effects Due to Shallow Trench Operations). The application scenarios selected in this safety assessment is the migrations of Co-60 and Cs-137 scenario through the shallow groundwater flow pattern in the NSD site. The SigmaPlot software is also used to determine the concentration equation in well water and river water. The final results showed the concentration of radionuclide in wells and streams below the provision. Radionuclide activity concentrations in well ranged from $10^{-10} \mathrm{~Bq} / \mathrm{m}^{3}$ to $10^{\circ} \mathrm{Bq} /$ $\mathrm{m}^{3}$ and in the river ranged from $10^{-15} \mathrm{~Bq} / \mathrm{m}^{3}$ to $10^{-1} \mathrm{~Bq} / \mathrm{m} 3$. The impact of radioactive waste of radionuclide Co- 60 and Cs-137 will decrease to the background radiation level at a distance less than $10 \mathrm{~m}$ and penetrate into the saturated layer up to $4 \mathrm{~m}$. In this study, an equation have been obtained that can predict radionuclide concentration patterns based on the distance and the depth of the ground surface against to the facility operation time..
\end{abstract}

Keywords: Radioactive waste; low level waste; Near Surface Disposal; PRESTO, Demonstration Plant

\section{INTRODUCTION}

The amount of radioactive waste in Indonesia is increasing in line with the increased utilization of nuclear energy in industrial, medical and research that related to the nuclear materials. Although it can be classified into lowlevel waste (LLW) because the waste is above the clearance level but the waste has a longlived radionuclide. Wastes are grouped in the LLW require strong isolation and detention for periods of up to several hundred years. Based on these characteristics, the type of storage that is suitable for the low activity waste is Near Surface Disposal (NSD) facility [1].

A study that needs to be done on the construction of demonstration plant near surface disposal is related to environmental safety aspects. An assessment of the radiological impact of the environment needs to be done on the Demonstration Plant NSD for radioactive waste that will be built. Environmental radioactivity level shall not exceed the limits of environmental radioactivity based on BAPETEN Chairman's Regulation No. 7 of 2013 on Environmental Radioactivity Limit Value. In addition, the value of the public doses received should not exceed the annual dose limit based on BAPETEN Chairman's Regulation No. 4 of 2013 on the Protection and Radiation Safety in Nuclear Energy Utilization.

Computer code PRESTO (Prediction of Radiological Effects Due To Shallow Trench Operations) is used to perform safety assessments as recommended by the IAEA in the ISAM (Improvement of Safety Assessment Methodologies) document for the

${ }^{1}$ Corresponding author. Email:pandu_dewanto@yahoo.com 
low activity waste at the NSD facility [3]. This is because the PRESTO can model the water infiltration including runoff, subsurface flow and atmospheric diffusion system.

This research aims to analyze possibilities of the presence of low activity of radionuclide releases mainly Co-60 and Cs-137 in the well and river water around the NSD site. The end result is expected to be determined by estimating the magnitude equation radionuclide concentrations in well and river water based on the distance and depth for a certain time period at the NSD site.

\section{REVIEW OF LITERATURE}

\section{Radionuclides release path}

Hydrologic transport is the main route of human receptors exposed to the radioactivity that contaminate soil or contaminated waste. The main pollutant source is water, which is a major driver for radionuclides leached from contaminated matrix, which comes from rain water. Precipitation water on the site can be derived from the infiltration into the soil, surface water runoff to the soil, or evaporation into the atmosphere. The water transport in this research uses PRESTO software that can determine:

Radionuclides Release: the concentration of radionuclides in the water that comes out from the site is using an empirical model based on an annual release fraction. The method for concentration calculating of the radionuclides in the water is an annual release fraction.

Radionuclide breakthrough time: Breakthrough time is the time for a radionuclide to migrate from the bottom of the trench to the wells, it is the number of vertical and horizontal transit time. Breakthrough time is approached by a model assuming that the radionuclide release is from a point source and the dispersion effects on the radionuclide transport can be negligible.
Concentration in the well water: To calculate the concentrations of radionuclides in the well, the flow rate of groundwater wells were calculated first

Contamination of surface runoff: Radionuclides dissolved in the groundwater is transported also to the stream through the flow toward the ground surface or deeper soil layers through percolation (seepage).

\section{Mathematical equationsformulation}

SigmaPlot software able to model the concentration of radionuclides. It's based on the time of the simulation to the distance or depth of the well. The equation obtained is considering the representation of data. The data analysis was done by non-liner regression using gaussian equation.

The model is a function of the independent variables (predictors) and one or more coefficients. Error is a random variation in the data that follows a certain probability distribution (in this case the Gaussian). Variations can come from various sources, but there is always a certain level when dealing with measured data. The model coefficients often have physical significance.

Gaussian equations for modeling graphs are used for conformance peak use equation

$$
\mathrm{y}=\sum_{\mathrm{i}=1}^{\mathrm{n}} \mathbf{a}_{1} \mathrm{el}^{\left.\backslash \varepsilon_{\mathrm{i}} /\right\rfloor}
$$

where $\mathrm{a}$ is the amplitude, $\mathrm{b}$ is the central point (location), c associated with a wide peak, $\mathrm{n}$ is the number of peaks.

\section{RESEARCH METHODS \\ The use of PRESTO software}

PRESTO software is designed by the Environmental Protection Agency (EPA), United State of America (USA). This software is designed to accommodate a variety of hydro geological and climatic conditions. It 
is also designed to handle of radionuclide leaching and transport of surface water through hydro geological conditions of saturated and unsaturated, taking into account the retardation of nuclides due to geochemical processes.

\section{Determination of radionuclide type analyzed}

Radionuclides Co-60 and Cs-137 are used as a reference in this study because these radionuclides are contained in all types of radioactive waste. The half live for the Co-60 is 5.271 years and for Cs-137 is 30.04 years. The half life is considered sufficient to represent the operation of the demonstration facility plan of NSD.

\section{Scenario releases of radioactive waste}

Radionuclides release scenario is done by identifying the migration pathways of radionuclide released from the system to the environment through water and soil. Release of radioactive substances from NSD facilities to the environment is affected by the condition of the solubility of radionuclide. This study uses a simulation with a span of 500 years of the NSD operation.

Observations were carried out starting from the first year and then in the 5 th year. After year 5, the simulation continues with multiples

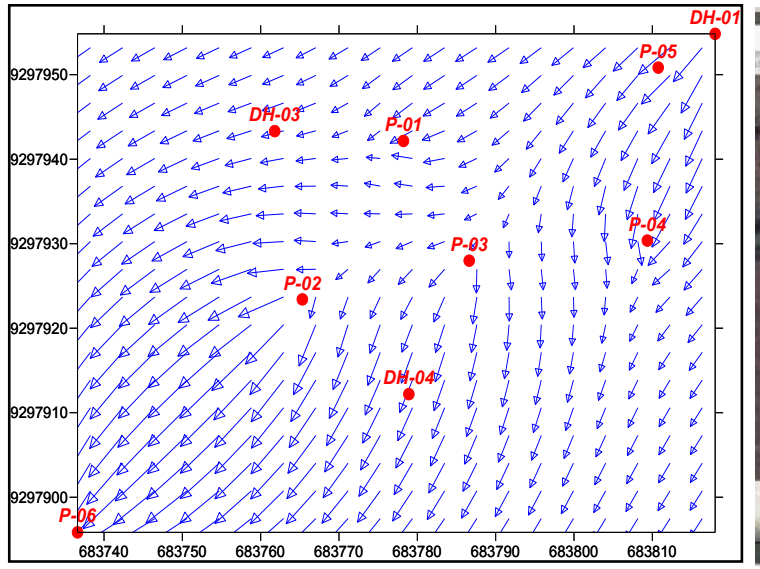

Figure 1. Shallow groundwaterflow pattern Insitearea NSD Source: [6] of 25 years to achieve the simulation in year 480. The observations were made from the center of NSD at a distance of wells from $10 \mathrm{~m}$ to $100 \mathrm{~m}$ with variation of the observation point $10 \mathrm{~m}, 15 \mathrm{~m}, 20 \mathrm{~m}, 25 \mathrm{~m}, 30 \mathrm{~m}, 35 \mathrm{~m}, 40 \mathrm{~m}, 45 \mathrm{~m}$, $50 \mathrm{~m}$ and $100 \mathrm{~m}$. Determination of the distance between the site and the well is based on the probability of radionuclide in water wells at the NSD site. At each point the distance from the well to the center NSD performed unsaturated layer depth variation with variation in depth of $4 \mathrm{~m}, 6 \mathrm{~m}, 8 \mathrm{~m}$ and $10 \mathrm{~m}$. The location of wells and streams as shown in Figure 1 is determined by the pattern of shallow ground water flow in the tread NSD area. Water flow pattern tends to lead to the southwest-west so that the location of wells simulation follows the direction of the water flow. The assumption is groundwater flow follows the hydraulic gradient that formed the contour of the ground water table.

Input data used in the PRESTO presented in Table 1.

\section{RESULTS AND DISCUSSION}

Radionuclide concentrations in water wells

Based on calculation that uses PRESTO software, the distance releases of radionuclides from the center of NSD to the wells and the

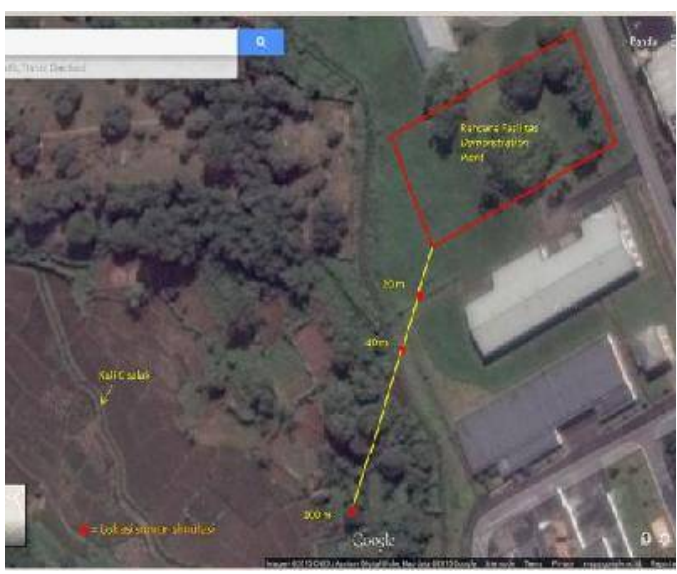

Figure 2. The location of simulations wells and streams (source : https://www.google.co.id/maps/) 
Table 1. Datainput to the software PRESTO

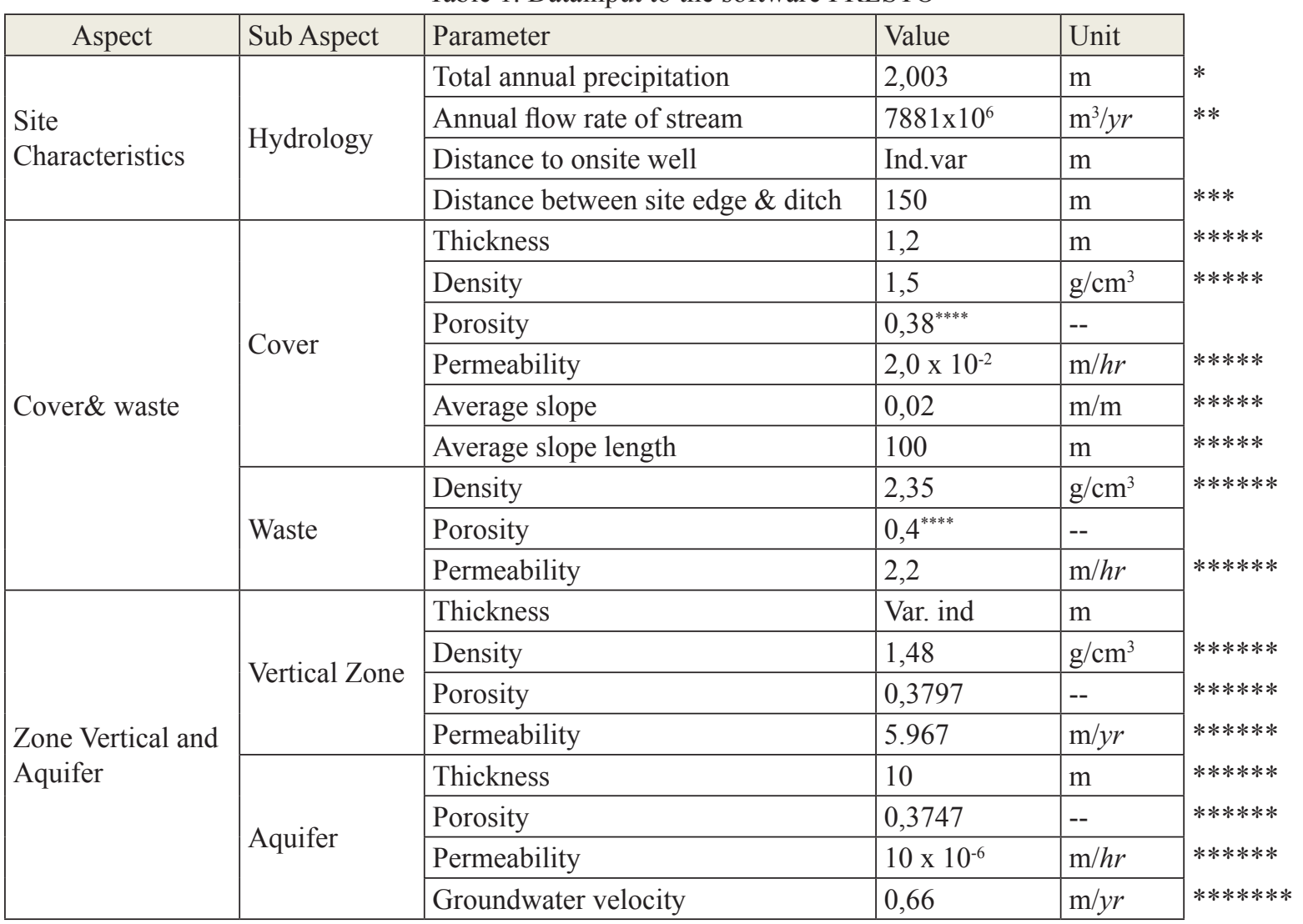

Source: *: BMKG- Stasiun Klimatologi Pondok betung Tangerang

$$
\text { ** :[7]; *** : [8]; **** : default PRESTO ; ***** : [9]; ****** :[5];******* : [10] }
$$

thickness of penetration of radionuclides into the saturated layer is found that Co-60 only have penetration up to a depth of $4 \mathrm{~m}$. As for Cs- 137 the peak penetration occurs at a depth of $4 \mathrm{~m}$ and continued to decline to a depth of $10 \mathrm{~m}$.

Maximum radionuclide concentrations found in monitoring wells for Co-60 ranged from $1,104 \times 10-10 \mathrm{~Bq} / \mathrm{m} 3$ up to $3,445 \times 10-4 \mathrm{~Bq} / \mathrm{m} 3$ and the maximum radionuclide concentrations for Cs-137 ranged from 8,380x10-2 Bq / $\mathrm{m} 3$ up to $1,022 \times 10+0 \mathrm{~Bq} / \mathrm{m} 3$. Radionuclides will disappear in the saturated layer above $10 \mathrm{~m}$. So that radionuclides will not reach the aquifer layer.

\section{Radionuclide concentrations in river}

The concentration of radionuclides Co-60 and Cs-137 decreased as a function of time, in which the determination time simulation throughout 500 years. The average peak concentrations of Co-60 is based on the thickness of penetration wells into the aquifer $(\mathrm{m})$ and the distance from the center of the NSD to the well (m) occurred in the year 79 up to the year 202, while Cs-137 occurred in the year 70 until the year 175 .

The distance to the river flow is fixed at $150 \mathrm{~m}$. By comparing radionuclide Co-60 and Cs-137 obtained that the maximum concentration in river flow occurs when the concentration in the monitoring wells located at a distance of $10 \mathrm{~m}$. The maximum concentration in streams ranging $5.86 \times 10-2 \mathrm{~Bq} / \mathrm{m} 3$ to $6.33 \times 10-2 \mathrm{~Bq} / \mathrm{m} 3$. The maximum concentration of Co- 60 and Cs- 137 in river flows can be found only in the first year, and its value is very small, and will continue to shrink until it disappears in the years hereinafter. 


\section{Conformity to Quality Standards}

BAPETEN Chairman's regulation No.7 of 2013 on Limit Value of Environmental Radioactivity, determine the level of radioactivity in the environment. The highest limit values specified in the activity concentration of radionuclide in the environment for $\mathrm{Co}-60$ is $3,0 \times 103 \mathrm{~Bq} / \mathrm{m} 3$, while for Cs-137 is $2,5 \times 102$ $\mathrm{Bq} / \mathrm{m} 3$. In the calculation results to the site NSD, the maximum concentration result of radioactive substances in the wells and streams that the radionuclide activity concentrations in the wells ranged from $10-10 \mathrm{~Bq} / \mathrm{m} 3$ to 100 $\mathrm{Bq} / \mathrm{m} 3$ and in the river ranged from 10-15 $\mathrm{Bq} / \mathrm{m} 3$ to $10-1 \mathrm{~Bq} / \mathrm{m} 3$. The concentrations of radionuclide in surface water around the site below the quality standard.

Although the results showed that the concentrations of radionuclide in surface water is still below the threshold quality standards, the monitoring of the level of radioactivity in the environment around the site NSD remains to be done for a maximum period of once a month.

\section{Estimated equations Radionuclide Concentration}

By using Sigmaplot software, we can define an equation to determine radionuclide concentrations in well water and river water. Data analysis was done by non-liner regression using Gaussian equation. The equations of each graph to determine the concentration in the wells and rivers (f) with units of $\mathrm{Bq} / \mathrm{m} 3$ are the following:

- Co-60 Concentration in well :

$$
\begin{gathered}
\mathrm{fW}=0,7926 \times \mathrm{e}^{-0.5\left[\left(\frac{x-101,6748}{28,6818}\right)^{2}+\left(\frac{y-2,9741}{2,8329}\right)^{2}\right]} \\
\mathrm{R}=0,8448 \quad \mathrm{R}^{2}=0,7136
\end{gathered}
$$

- Cs-137 Concentration in well:

$$
\begin{gathered}
\mathrm{fW}=0,0003 \times \mathrm{e}^{-0.5\left[\left(\frac{x-87,1915}{7,5074}\right)^{2}+\left(\frac{y-8,96087}{0,4187}\right)^{2}\right]} \\
\mathrm{R}=0,8263 \quad \mathrm{R}^{2}=0,6828
\end{gathered}
$$

- Co-60Concentration in river :

$$
\text { fr }=0.1096 \times \mathrm{e}^{-0.5\left[\left(\frac{x-0.9998}{1,7092}\right)^{2}+\left(\frac{y-8.9552}{0,9884}\right)^{2}\right]}
$$

$$
\mathrm{R}=1,0000 \quad \mathrm{R}^{2}=1,0000
$$

- Cs-137 Concentration in river:

$$
\begin{gathered}
\mathrm{fr}=0,1186 \times \mathrm{e}^{-0.5\left[\left(\frac{x-0,9996}{1,8680}\right)^{2}+\left(\frac{y-8,9581}{0,9587}\right)^{2}\right]} \\
\mathrm{R}=1,0000 \quad \mathrm{R}^{2}=1,0000
\end{gathered}
$$

In the equation for determining the concentration of radionuclide in wells (fw), $\mathrm{x}$ express the depth of the well and $y$ is the year of observation. While the equation for determining the concentration of radionuclide in the river (fr), $x$ expressed the distance well from the site and $y$ declared the year of observation.

The equation shows that the coefficient of determination (R2) for radionuclide concentrations in well for Co-60 and Cs-137 respectively are 0,71 and 0,68 . It means that the ability of the independent variable (the depth of well) in explaining the variance of the dependent variable (the concentration of radionuclide) are $71 \%$ and $68 \%$. It means that there are $29 \%$ and $32 \%$ variance dependent variable that can be influenced by other factors.

By using the equation we can determine and predict the radionuclide concentration pattern of Co-60 and Cs-137 to a certain depth and distance at the well and the stream (Figure 3 and Figure 4). The distribution pattern of radionuclide in the well water and river water obtained only can be applied to the 


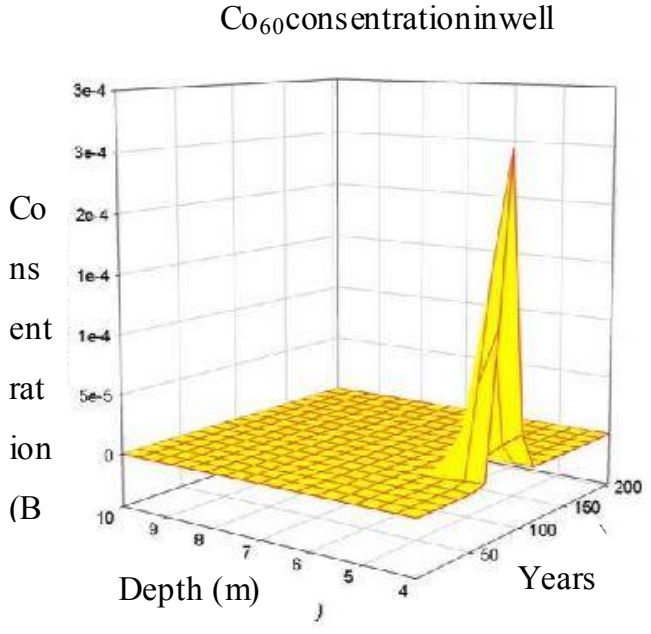

a. $\operatorname{Co}-60$

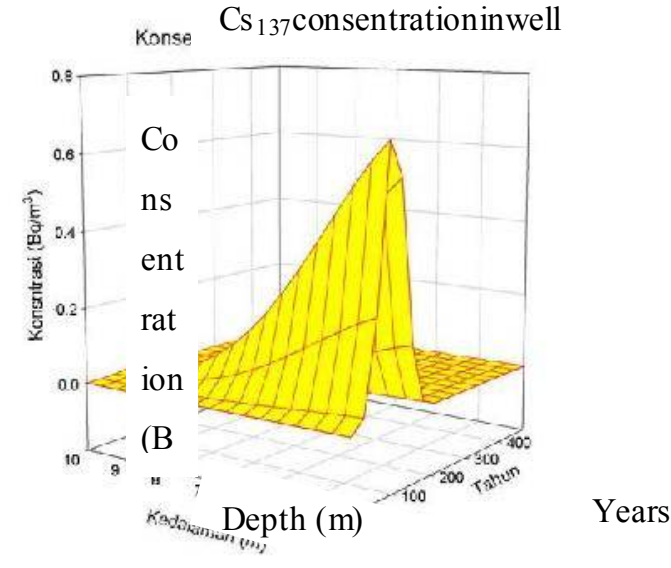

b.Cs -137

Figure 3. The pattern of distribution of radionuclide in water wells

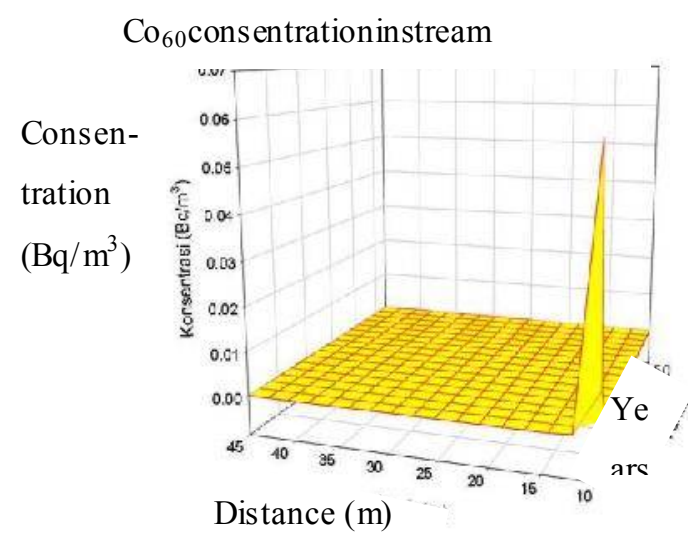

a. $\mathrm{Co}-60$

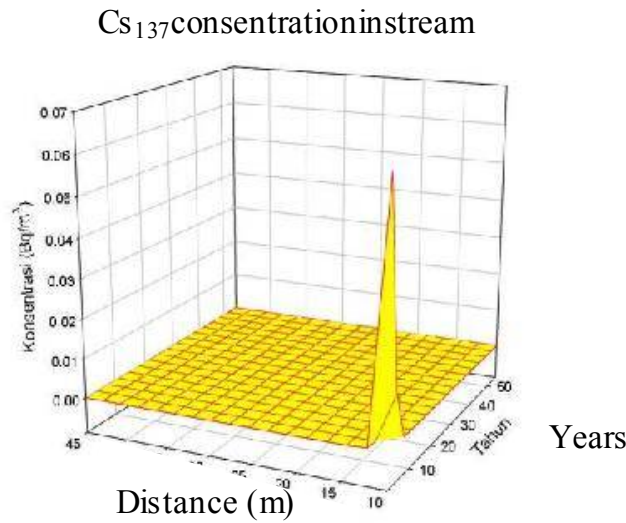

b.Cs -137

Figure 4. The pattern of distribution of radionuclide in river water

environmental the NSD site in Serpong Nuclear Zone. This is because each site has different characteristics.

\section{CONCLUSION}

- The concentration of radionuclide in surface water around site below the quality standard refers to the BAPETEN chairman's regulation No. 7 of 2013 on Environmental Radioactivity Limit Value, where standard for the maximum concentration of radioactive substances in water bodies range from $102 \mathrm{~Bq} / \mathrm{m} 3$ to $107 \mathrm{~Bq} / \mathrm{m} 3$. The maximum concentration of radioactive on NSD site that obtained from the calculation are the radionuclide activity concentrations in the wells ranged from $10-10 \mathrm{~Bq} / \mathrm{m} 3$ to $100 \mathrm{~Bq} /$ $\mathrm{m} 3$ and in the river water ranged from 10-15 $\mathrm{Bq} / \mathrm{m} 3$ to $10-1 \mathrm{~Bq} / \mathrm{m} 3$.

- The equations obtained can determine and predict the patterns of Co-60 and Cs- 137 radionuclide concentration with specified depth and distance in well and river water to NSD site in Serpong Nuclear Zone to be built. 


\section{REFERENCES}

BAPETEN. (2013). Peraturan Kepala BAPETEN Nomor 4 Tahun 2013 Tentang Proteksi dan Keselamatan Radiasi Dalam Pemanfaatan Tenaga Nuklir. Jakarta: Badan Pengawas Tenaga Nuklir.

BAPETEN. (2013). Peraturan Kepala BAPETEN Nomor 7 Tahun 2013 Tentang Nilai Batas Radioaktivitas Lingkungan. Jakarta: Badan Pengawas Tenaga Nuklir.

BPL-PTLR.(2011). Database Limbah Radioaktif PTLR. Serpong: PTLR-BATAN .

Hung, C.-Y. (2000). User's Guide For PRESTOEPA-CPG/POP Operation System, Version 4.2. Washington DC: U.S. Environmental Protection Agency, Office of Radiation and Indoor Air.

IAEA. (1994). Near Surface Disposal of Radioactive Wastes, Safety Series No. 111S.3. Vienna: International Energy Atomic Agency.

IAEA. (2004). Safety Assessment Methodologies for Near Surface Disposal Facilities. Vienna: International Atomic Energy Agency.

IAEA. (2009). Classification of Radioactive Waste, General Safety Guide No. GSG-1). Viena: International Atomic Energy Agency.

IAEA. (2011). Disposal of Radioactive Waste, Specific Safety Requirements (No. SSR-5). Vienna, Austria: International Atomic Energy Agency.
Lubis, E., \& Untara. (1996). Migrasi Co60 dan Cs137 dalam tanah jenuh dan tak jenuh di PPTA Serpong. Jakarta: PSPKR-Batan.

PPGN-BATAN. (2010). Penylidkan Geoteknik: Penyelidikan Geologi Teknik dan Hidrogeolgi Tapak asiltas Demo Plant PLLR di PPTN Serpong. Jakarta: PTLR- BATAN.

PPGN-BATAN. (2010). Studi geohidrologi dan karakteisasi akuifer : penyelidikan geologi teknik dan hidrogeologi tapak fasilita demo plant PLLR di PPTN serpong. Jakarta: PTLR - BATAN.

Sucipta. (2012). Optimasi penempatan disposal demo dalam lingkungan geologi Kawasan Nuklir Serpong. Serpong: PTLR-BATAN.

Sumantri, T., \& Sucipta. (2012). Pemantauan kedalaman muka air tanah tapak Demo disposal tahun 2011. Serpong: PTLRBATAN.

Twining, J., Hughes, C., Harrison, J., \& Hankin, S. (2011). Biotic, temporal and spatial variability of tritium concentrations in transpirate samples collected in the vicinity of a near-surface low-level nuclear waste disposal site and nearby research reactor.

Yim, M. S., \& Simonson, S. A. (2000). Performance Assessment Models for Low Level Radioactive Waste Disposal Facilities: A Review (Vol. 36). 